\title{
ANALISIS PENGARUH CURRENT RATIO, INVENTORY TURN OVER DAN DEBT TO EQUITY RATIO PADA PERUSAHAAN OTOMOTIF DAN PRODUK KOMPONENNYA PADA BURSA EFEK INDONESIA ( 2010 - 2013)
}

\author{
Andy Kridasusila, Windasari Rachmawati
}

\begin{abstract}
ABSTRAK
Penelitian ini dilakukan untuk menguji pengaruh variabel Current Ratio, Inventory Turnover, Debt to Equity Ratio (DER), terhadap Return on Asset (ROA) pada perusahaan automotive and allied products yang terdaftar di Bursa Efek Indonesia (BEI) periode 2010-2013. Sampel penelitian sebanyak 17 perusahaan otomotif dan produk komponen.

Hasil dari penelitian menggunakan analisis regresi berganda, yang menunjukkan bahwa current ratio, inventory turn over dan debt to equity ratio mempunyai pengaruh secara simultan terhadap return on assets, dan secara parsial seluruh variabel independen (current ratio, inventory turn over dan debt to equity ratio) berpengaruh secara signifikan terhadap return on assets pada perusahaan. Variabel paling dominan dalam penelitian ini yang berpengaruh terhadap return on assets adalah debt to equity ratio.

Kata Kunci: Current Ratio, Inventory Turnover, Debt to Equity Ratio, dan Return on Asset (ROA)
\end{abstract}

\begin{abstract}
This study is performed to examine the effect of Current Ratio, Inventory turnover, Debt to Equity Ratio (DER) toward Return on Asset (ROA) in Automotive and allied product those are listed in Indonesian Stock Exchange (ISX). The objective of this study is to scale and analyze the effect of the companies financial ratios performance (Current Ratio, Inventory Turnover, DER) toward ROA in automotive and allied product that is listed in ISX over period 2009 -2013. Research sample consist of 17 Automotive and Allied products companies.

The result of research is using multiple regression analyzing, which show that current ratio, inventory turn over and debt to equity ratio to return on assets has a significant effect in simultaneous on company performance, and partially all of independent variable (current ratio, inventory turn over and debt to equity ratio to return on assets) has a significant effects on company performance. The most dominant variable in this research which have an effect on financial performance is debt to equity ratio to return on assets.
\end{abstract}

Keywords: Current Ratio, Inventory Turnover, Debt to Equity Ratio, and Return on Asset (ROA)

\section{Pendahuluan}

Dalam era MEA 2016 memenangkan persaingan merupakan kunci pokok dalam keunggulan kompetitif.Hal ini melibatkan kinerja keuangan perusahaan.Oleh karena itu penting sekali untuk mendalami studi kinerja keuangan perusahaan. Return on assets merupakan indicator untuk mengukur kinerja keuangan perusahaan dan merupakan rasio profitabilitas yang digunakan untuk mengukur effektivitas perusahaan di dalam menghasilkan keuntungan dengan memanfaatkan total aktiva yang dimilikinya. Return on assets ini penting karena berkaitan dengan profitabilitas perusahaan. Laba merupakan hasil kerja yang diharapkan oleh manajemen.return on assets merupakan rasi antara laba sesudah pajak atau net income after tax (NIAT) terhadap total assets.Bila ROA tinggi maka manajemen mempunyai dua pertimbangan apakah tidak membagikan dividen atau membagikan dividen.

Akan tetapi krisis financial global pada tahun 2008 dampaknya telah mempengaruhi kinerja sektor otomotif di Indonesia terutama pada tahun 2009. Menurut laporan Gabungan 
Industri Kendaraan Bermotor Indonesia (Gaikindo) tingkat produksi dan penjualan mobil pada tahun 2009 mengalami penurunan dibandingkan pada tahun sebelumnya. Tingkat produksi merosot menjadi 464.815 unit pada tahun 2009 dibandingkan tahun sebelumnya 600.628 unit atau mengalami penurunan sebesar $22,6 \%$, sedangkan tingkat penjualan melemah $19,9 \%$, pada tahun 2008 penjualan tercatat sebanyak 603.774 unit menjadi hanya 483.548 unit pada tahun 2009, penurunan penjualan ini disebabkan oleh melemahnya nilai rupiah yang menyebabkan kenaikan harga mobil, sehingga konsumen menunda untuk membeli mobil. Memasuki tahun 2010 pasar mobil mulai bergairah karena ekonomi dunia mulai pulih. Setiap rumah rata-rata memiliki setidaknya satu atau bahkan lebih kendaraan bermotor, namun kondisi pasar otomotif Indonesia kembali kurang bergairah di awal tahun 2015. (kompas.com).

Laporan keuangan dirancang bagi pengusaha, investor dan kreditor dimana mereka harus bisa memahami bagaimana membaca, mengartikan serta menganalisis angka - angka yang terdapat di dalam laporan keuangan. Data di atas menunjukkan bahwa current ratio rata - rata pada tahun 2010 sampai tahun 2013 mengalami penurunan pada tahun 2011. Berbeda dengan debt equity to ratio yang mengalami penurunan rata - rata selama dua tahun yaitu 2011 dan 2012. Sedangkan inventory turn over rata - rata tertinggi selama tahun 2010 - 2013 di tahun 2010. Perbedaan hasil penelitian di atas variabel - variabel yang berpengaruh terhadap profitabilitas (ROA) dikemukakan oleh peneliti terdahulu, antara lain:

1.Tuasikal (2002) menyatakan bahwa current ratio (CR) lebih dapat memprediksi kinerja perusahaan manufaktur dibandingkan pada perusahaan non manufaktur, sedangkan penelitian ardiansyah (2004) current ratio tidak berpengaruh signifikan terhadap kinerja TELAAH PUSTAKA

\section{Rasio profitabilitas (profitability ratio)}

margin laba kotor $=$ penjualan bersih - HPP Penjualan bersih

Rasio ini menjelaskan laba dan perusahaan yang berhubungan dengan penjualan, dikurangi biaya untuk memproduksi barang yang dijual.Rasio tersebut merupakan pengukur efisiensi operasi
Laporan keuangan melaporkan posisis keuangan suatu perusahaan pada suatu waktu tertentu dan pada periode yang lalu (Astuti: 2002,29)

Perusahaan yang dipilih untuk menjadi obyek penelitian ini adalah perusahaan automotive and allied products.Meskipun perusahaan ini memproduksi kebutuhan manusia tetapi berbeda dalam hal menghasilkan keuntungan. Berdasarkan laporan keuangan perusahaan yang telah di publikasikan dalam Indonesia capital market directory ( ICMD) tahun 2013 pada periode 4 tahun terakhir yaitu 2010 - 2013, perusahaan automotive and alliiied product memperoleh keuntungan (ROA).

Tabel

Rata - Rata Current Ratio, Debt to Equity Ratio dan Inventory Turn Over Selama Tahun 2010 2013

\begin{tabular}{|l|l|l|l|l|l|}
\hline No & \multirow{2}{*}{ Ket } & \multicolumn{3}{|l|}{ Tahun } \\
\cline { 3 - 6 } & & 2010 & 2011 & 2012 & 2013 \\
\hline 1 & CR & 1.648 & 1.548 & 1.620 & 1.755 \\
\hline 2 & DER & 1.414 & 1.318 & 1.312 & 1.734 \\
\hline 3 & ITO & 5.245 & 4.852 & 4.741 & 4.857 \\
\hline
\end{tabular}

Sumber : Data sekunder yang diolah

perusahaan.2.Penelitian terhadap inventoryturn over di dasarkan atas adanya research gap dari hasil penelitian terdahulu antara asyik dan sulistyo (2000) dengan Campbell (2002). Asyik dan sulistyo (2000) menunjukkan pengaruh positif inventory turn over terhadap return on asset, sedang Campbell (2002) tidak menunjukkan adanya pengaruh inventory turn over terhadapp return on asset.

3.Debt to equity ratio diteliti sulistyawan (2005) dan kwandinata (2005) menunjukkan pengaruh positif terhadap return on asset, sedangkan Campbell (2002) dan bardosa dan louri (2003) menunjukkan pengaruh negative. Sehingga perlu penelitian lebih lanjut.

ada dua jenis yaitu profitabilitas dalam penjualan atau profitabilitas dalam investasi.

perusahaan, serta merupakan indikasi dan penetapan harga produk.

margin laba bersih $=\underline{\text { EAT }}$

Penjualan bersih

Margin laba bersih adalah ukuran profitabilitas perusahaan dan penjualan setelah memperhitungkan semua biaya dan pajak

Jurnal Dinamika Sosial Budaya, Volume 18, Nomor 1, Juni 2016 
penghasilan. Margin tersebut menjelaskan penghasilan bersih per penjualan. Jika margin laba kotor tidak terlalu banyak berubah sepanjang beberapa tahun, tetapi margin laba bersihnya menurun selama periode waktu yang sama, penyebabnya di prediksi biaya penjualan, umum dan administrasi yang terlalu tinggi dibandingkan dengan penjualan. Kejadian ini bisa disebabkan oleh harga yang lebih rendah Variabel yang digunakan dalam penghitungan Return On Assets

Rasio likuiditas (liquidity) secara umum dapat di artikan sebagai kemampuan perusahaannya dalam membayar hutang hutangnya, yang telah jatuh tempo, Lancaster et,al. (1998;28). Semakin tinggi current ratio semakin kecil resiko kegagalan suatu erusahaan dalam memenuhi kewajiban jangka pendeknya. Akibatnya resiko yang ditanggung pemegang saham akan semakin kecil (Ang, 1997). Menurut Sartono (2001:206), semakin tinggi current ratio berarti semakin besar kemampuan perusahaan untuk memenuhi kewajiban jangka pendek. Jika nilai current ratio dari suatu perusahaan tinggi akan mengurangi ketidakpastian bagi investor, namun mengindikasikan adanya dana yang menganggur (idle cash) sehingga profitabilitas akan berkurang. Current yang terlalu tinggi menunjukkan kelebihan uang kas atau aktiva lancar lainnya di bandingkan dengan yang dibutuhkan sekarang. Rasio ini dapat dirumuskan sebagai berikut, (Weston dan Copeland, 1995):

Current Ratio : current sset

\section{current Liabilitis}

Definisinya menunjukkan berapa kali jumlah persediaan barang dagangan dig anti atau di jual dalam satu tahun. Perputaran yang tinggi menunjukkan tingkat persediaan yang ada dalam kategori baik. Sedangkan menurut abdul halim, 2007 inventory turnover merupakan rasio aktivitas yang digunakan untuk mengukur sampai seberapa besar effektivitas perusahaan dalam menggunakan sumber dayanya yang berupa asset. Semakin tinggi rasio ini semakin

\section{Return on Assets (ROA)}

ROA digunakan untuk mengukur kinerja keuangan perusahaan-perusahaan multinasional, khususnya jika dilihat dari sudut atau efisiensi yang rendah juga. Profitabilitas dalam hubungannya dengan investasi menghubungkan laba dengan investasi. Salah satu pengukurannya adalah seberapa besar pengembalian atas investasi (return on investment - ROI) atau tingkat pengembalian atas aktiva (return on asset - ROA)

Return on investment $=\underline{\text { laba bersih setelah pajak }}$

efisiensi penggunaan asset dan semakin cepat pengembalian dana dalam bentuk kas.

\section{Debt to equity ratio (DER)}

Rasio yang mengukur tingkat penggunaan hutang (leverage) terhadap total shareholder's equity yang dimiliki perusahaan. Secara matematis debt to equity ratio adalah perbandingan antara total hutang atau total debts dengan total shareholder's equity (Ang, 1997).Menurut Brealey, et.all (2008:75), rasio solvabilitas yang aman digunakan adalah rasio hutang terhadap ekuitas atau debt to equity ratio (DER). DER akan berbeda tergantung pada sifat bisnis dan variabilitas arus kas.

Menurut Robert Ang (1997) rasio ini menunjukkan komposisi dari total hutang terhadap total ekuitas. Semakin tinggi DER menunjukkan komposisi total hutang semakin besar di banding dengan total modal sendiri, sehingga berdampak semakin besar beban perusahaan terhadap pihak luar (kreditur). Sumber-sumber pendanaan perusahaan dapat diperoleh dari dalam perusahaan (internal) dan dari luar perusahaan (eksternal). Brigham (1983) menyatakan bahwa dalam mengembangkan target capital structure perlu dilakukan analisis dari banyak faktor dengan mempertimbangkan kondisi keuangan perusahaan. Sumber dana dari pihak luar diperoleh dari pinjaman atau utang (baik hutang jangka pendek maupun hutang jangka panjang): sedangkan sumber dana dari pihak internal diperoleh dari modal saham (equity) dan laba tak dibagi (retained earning). Debt to Equity Ratio dapat dirumuskan sebagai berikut:

Debt to equity ratio $=$ Total hutang Jumlah modal sendiri pandang profitabilitas dan kesempatan investasi. ROA sering dipakai manajemen untuk mengukur kinerja keuangan perusahaan dan menilai kinerja operasional dalam 
memanfaatkan sumber daya yang dimiliki perusahaan, disamping perlu mempertimbangkan masalah pembiayaan terhadap aktiva tersebut. Nilai ROA yang semakin mendekati 1, berarti semakin baik profitabilitas perusahaan karena setiap aktiva yang ada dapat menghasilkan laba.

\section{Pengaruh Variabel - Variabel Independen Terhadap ROA}

Pengaruh current ratio terhadap ROA

Nilai current ratio yang tinggi dan suatu perusahaan akan mengurangi ketidakpastian bagi investor, namun mengindikasikan adanya dana yang menganggur (idle cash) sehingga akan mengurangi tingkat profitabilitas perusahaan, akibatnya Return on Assets semakin kecil. Dengan demikian di duga semakin besar nilai current ratio maka semakin kecil return on asset (Ang, 1997). Berdasarkan uraian tersebut maka di ambil hipotesis:

$\mathrm{H} 1$ = Terdapat pengaruh negatif current ratio terhada return on asset pada perusahaan automotive and allied products.

Pengaruh inventory turnover terhadap ROA

Inventory turnover menunjukkan berapa kali perputaran persediaan selama satu tahun.Semakin tinggi perutarannya menunjukkan perusahaan semakin effisien dalam menekan biaya atas persediaan tersebut. Oleh karena itu bisa di asumsikan hubungan antara inventory turn over dengan return on asset adalah positif. Semakin besar inventory turnover akan semakin baik karena berarti akan semakin efisien seluruh aktiva yang digunakan untuk menunjang kegiatan penjualan (Robert ang, 1997).

$\mathrm{H} 2$ = terdapat pengaruh positif inventory turn over terhadap return on asset pada perusahaan automotive and allied products.

pengaruh Debt to equity ratio terhadap ROA Semakin tinggi DER akan memperngaruhi besarnya laba (return on asset) yang dicapai oleh perusahaan. Ang (1997).

Semakin tinggi hutang sebagai sumber dana dari hutang tersebut memberikan hasil yang lebih tinggi dari pengorbanan akan meningkatkan profitabilitas. Hasil lebih tinggi dari pengorbanan rasio hutang menghasilkan dampak positif maka profitabilitas meningkat.Maka pengaruh DER pada ROA positif.

$\mathrm{H} 3$ = terdapat pengaruh positif DER terhadap ROA pada perusahaan automotive and allied products.

\section{Penelitian Terdahulu}

Semakin besar return on asset's menunjukkan kinerja perusahaan semakin baik, karena return semakin besar ( limpaphayom dan ngamwutikul, 2004). Menurut Huynh dan JHY - tay ( 2010) berdasarkan studi mereka padadata sekunder yang dikumpulkan dari perusahaan yang terdaftar di Bursa Vietnam pasar untuk periode 2006-2008. Temuan mereka menunjukkan bahwa ada hubungan negatif yang kuat antara profitabilitas, diukur melalui laba kotor dan uang tunai siklus konversi . Ini berarti bahwa sebagai konversi kas meningkat, hal itu akan menyebabkan penurunan profitabilitas perusahaan.

Sedangkan menurut Subalno, (2009:42: dikutip dari fitri (2010)), ROA digunakan untuk mengukur kinerja keuangan perusahaanperusahaan multinasional, khususnya jika dilihat dari sudut pandang profitabilitas dan kesempatan investasi. ROA sering dipakai manajemen untuk mengukur kinerja keuangan perusahaan dan menilai kinerja operasional dalam memanfaatkan sumber daya yang dimiliki perusahaan, disamping perlu mempertimbangkan masalah pembiayaan terhadap aktiva tersebut. Nilai ROA yang semakin mendekati 1, berarti semakin baik profitabilitas perusahaan karena setiap aktiva yang ada dapat menghasilkan laba. Dengan kata lain, semakin tinggi nilai ROA maka semakin baik kinerja keuangan perusahaan tersebut. ROA yang negatif disebabkan laba perusahaan dalam kondisi negatif pula atau rugi, hal ini menunjukkan kemampuan dari modal yang diinvestasikan secara keseluruhan belum mampu untuk menghasilkan laba.

\section{Kerangka Pemikiran}

Berdasarkan telaah pustaka maka variabel dependen dalam penelitian ini adalah return on asset (ROA) sedangkan DER, inventory turn over dan current ratio digunakan sebagai variabel independen 


\section{Gambar 1}

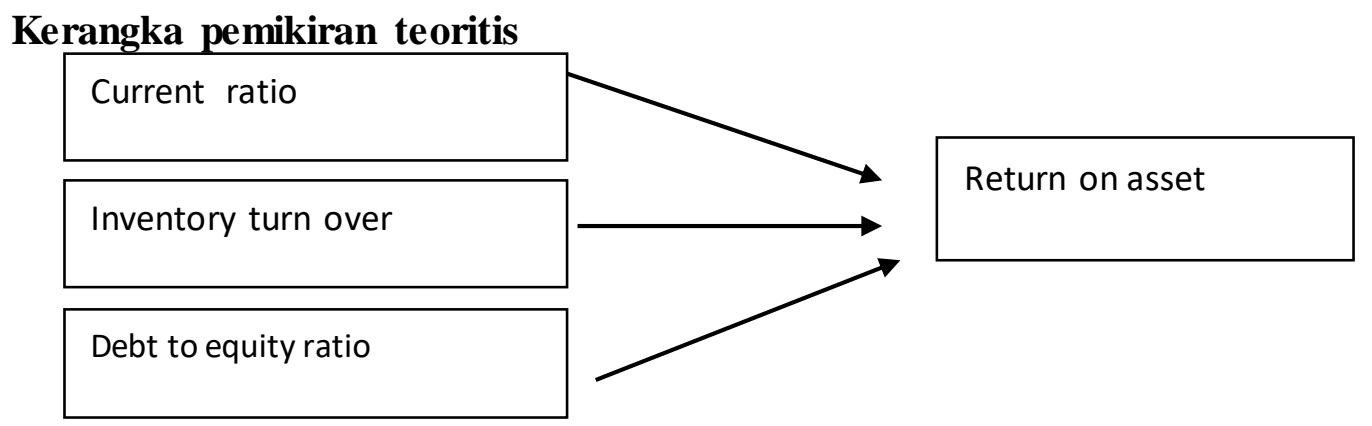

\section{METODE PENELITIAN}

Populasi yang digunakan dalam penelitian ini adalah perusahaan automotive and allied products yang tercatat di bursa efek Indonesia (BEI) dalam periode penelitian 2010 - 2013. Dari populasi sebanyak 19 perusahaan diperoleh sebanyak 17 perusahaan otomotif and allied product sebagai sampel.

Tersedia data current ratio, inventory turn over, debt to equity ratio dan return on asset selama periode penelitian 2010 - 2013.

Berdasarkan pada criteria pengambilan sampel di atas, maka jumlah sampel yang digunakan dalam penelitian ini adalah 17 Indonesian capital market directory selama tahun $2010-2013$.

\section{Analisa Data}

Untuk menguji kekuatan variabel - variabel penentu (current ratio, inventory turn over, dan debt to equity ratio) terhadap return on asset, maka dalam penelitian ini digunakan analisis regresi berganda dengan persamaan kuadrat terkecil (ordinary least square - OLS ) dengan modal dasar sebagai berikut: (Gujarati, 1995)

$$
\mathrm{Y}=\mathrm{a}+\mathrm{b} 1 \mathrm{X} 1+\mathrm{b} 2 \mathrm{X} 2+\mathrm{b} 3 \mathrm{X} 3
$$

Keterangan : $\mathrm{Y}=$ return on asset

$$
\mathrm{a}=\text { konstanta }
$$

$\mathrm{b} 1, \mathrm{~b} 2, \mathrm{~b} 3=$ koefisien regresi

$\mathrm{X} 1=$ current ratio

$\mathrm{X} 2=$ inventory turn over

$\mathrm{X} 3=$ debt to equity ratio

Nilai koefisien regresi sangat berarti sebagai dasar analisis. Koefisien b akan bernilai positif (+) jika menunjukkan hubungan yang searah antara variabel independen dengan
Sampel penelitian di ambil dengan metode purposive sampling dimana sampel yang digunakan adalah perusahaan yang memenuhi criteria sebagai berikut:

Perusahaan yang digunakan adalah yang telah go public di bursa efek Indonesia (BEI) pada periode penelitian 2010 - 2013.

perusahaan otomotif and allied product antara lain:

Data yang dikumpulkan adalah data sekunder dengan mengumpulkan data laporan keuangan dari

variabel dependen, artinya kenaikan variabel independen akan mengakibatkan kenaikan variabel dependen, begitu pula sebaliknya jika variabel independen mengalami penurunan. Sedangkan nilai $b$ akan negative jika menunjukkan hubungan yang berlawanan, artinya kenaikan variabel independen akan mengakibatkan penurunan variabel dependen, demikian pula sebaliknya.

Model persamaan yang diperoleh dari pengolahan data diupayakan tidak terjadi gejala multikolinieritas, heterokedasitas dan autokorelasi. Untuk mengetahui ada tidaknya gejala - gejala tersebut akan dilakukan uji terlebih dahulu dengan uji asumsi klasik.

\section{Pengujian asumsi klasik} Normalitas

Uji normalitas bertujuan menguji apakah dalam model regresi, variabel dependen dan variabel independen keduanya mempunyai distribusi normal atau tidak. Model regresi yang 
baik adalah memiliki distribusi normal atau mendekati normal. Sedangkan menurut Purwoto (2007;96) pengujian tersebut dapat menggunakan metode grafis normal $\mathrm{P}-\mathrm{P}$ Plot.Menurut singgih santoso (2000:124) ada beberapa cara mendeteksi normalitas dengan cara melihat penyebaran data (titik) pada sumbu diagonal dari grafik. Dasar pengambilan keputusan dalam uji normalitas adalah:

Jika data menyebar disekitar garis diagonal dan mengikuti garis diagonal, maka model regresi memenuhi asumsi normalitas.

Jika data menyebar dari garis diagonal dan atau tidak mengikuti arah garis diagonal, maka model regresi tidak memenuhi asumsi normalitas.

\section{Multikolonieritas}

Pengujian asumsi kedua adalah uji multikolonieritas (multicolonierity) antara variabel - variabel independen yang masuk ke dalam model. Uji variance inflation faktor (VIF) yang dihitung dengan rumus sebagai berikut:

$$
\mathrm{VIF}=1 / \text { Tolerence }
$$

Jika VIF lebih besar dari 10, maka antara variabel bebas (independent variable) terjadi persoalan multikolinearitas (Imam Ghozali, 2001).

\section{Uji heteroskedesitas}

\section{Pengujian hipotesis}

Pengujian terhadap masing - masing hipotesis yang diajukan dapat dilakukan dengan cara sebagai berikut:

Uji signifikansi (pengaruh nyata) variabel independen (Xi) terhadap variabel dependen (Y) baik secara parsial maupun secara bersama - sama pada hipotesis 1 ( H1) sampai dengan hipotesis 10 (H10) dilakukan dengan uji statistic ( $\mathrm{t}$ test) dan uji $\mathrm{F}$ (F test) pada level 5\% $(\alpha=0,05)$

Uji t - statistic

Uji keberartian (bi) dilakukan dengan statistic t. hal ini digunakan untuk menguji koefisien regresi secara parsial dari variabel independennya. Adapun hipotesis dirumuskan sebagai berikut :

Hi : bi $\neq 0$

Artinya terdapat pengaruh yang signifikan dari variabel independen $\mathrm{Xi}$ terhadap variabel dependen (Y).

Nilai t-hitung dapat dicari dengan rumus (Gujarati, 1995)

t hitung $=\underline{\text { koefisien regresi (bi) }}$
Bhuono agung nugroho (2005:62) heterokedasitas menguji terjadinya perbedaan variance residual suatu periode pengamatan ke periode pengamatan selanjutnya. Dalam hal ini model regresi yang baik adalah tidak terjadi heteroskedasitas.

Cara memprediksi ada tidaknya heteroskedasitas pada suatu model dapat dilihat pada gambar scatterpolt model

\section{Uji autokorelasi}

Maurice G Kendall dan William R, Buckland, A Dictionary of Statistical Term mengatakan bahwa uji autokorelasi merupakan korelasi antar anggota seri observasi yang di susun menurut urutan tempat (seperti data cross section) atau korelasi pada dirinya sendiri.

Pengambilan keputusan ada tidaknya autokorelasi menurut Santoso (2002:218) dengan cara melihat besaran Dubrin-Watson (DW) sebagai berikut:

- angka D-W dibawah -2 , berarti ada autokorelasi positif,

- angka D-W diantara -2 sampai +2 berarti tidak ada autokorelasi,

- angka D-W di atas +2 , berarti ada autokorelasi negatif.

\section{Standard error bi}

Jika $\mathrm{t}$ hitung $>\mathrm{t}$ tabel $(\alpha, \mathrm{n}-\mathrm{k}-\mathrm{l})$, maka Ho ditolak; dan

Jika t hitung $<\mathrm{t}$ tabel $(\alpha, \mathrm{n}-\mathrm{k}-\mathrm{l})$, maka Ho diterima.

Uji f - statistic

Uji ini digunakan untuk menguji keberatian pengaruh dari seluruh variabel independen secara bersama - sama terhadap variabel dependen.

Hipotesis ini dirumuskan sebagai berikut:

$\mathrm{H} 1: \mathrm{b} 1, \mathrm{~b} 2, \mathrm{~b} 3, \mathrm{~b} 4, \mathrm{~b} 5 \neq 0$

Artinya terdapat pengaruh yang signifikan secara bersama - sama dari variabel independen (X1 sampai X3) terdapat variabel dependen (Y).

Nilai F - hitung dapat dicari dengan rumus: (Gujarati, 1995)

F hitung $=\underline{\mathrm{R}^{2} /(\mathrm{k}-1)}$

$$
\left(1-\mathrm{R}^{2}\right) /(\mathrm{N}-\mathrm{k})
$$

Jika f hitung > f tabel (a, n-k-1), maka Ho ditolak; dan

Jika $\mathrm{f}$ hitung < $\mathrm{f}$ tabel (a, n-k-1), maka Ho diterima.

\section{Koefisien Determinasi}


Merupakan besaran yang memberikan informasi goodness of fit dari persamaan regresi, yaitu memberikan proporsi atau presentase kekuatan pengaruh yang menjelaskan (X1, $\mathrm{X} 2, \mathrm{X} 3)$ secara simultan terhadap variabel dependen (Y). koefisien determinasi $\left(\mathrm{R}^{2}\right)$ digunakan untuk mengukur seberapa jauh kemampuan model dalam menerangkan variabel dependen. Nilai koefisien determinasi adalah PEMBAHASAN

\section{Analisis Data Kuantitatif}

Data yang dibutuhkan dalam penelitian ini adalah laporan keuangan perusahaan automotive and allied products yang sudah dan masih terdaftar di Bursa Efek Indonesia selama periode tahun 2010 sampai 2013.

Kriteria pengambilan sampel pada penelitian ini adalah sebagai berikut:

1. Perusahaan yang sudah dan masih terdaftar di Bursa Efek Indonesia dari tahun 2010 - 2013

2. Memberikan laporan keuangan secara periodik ke Bursa Efek Indonesia selama periode penelitian.

3. Perusahaan mendapatkan laba setelah pajak (EAT) yang positif selama tahun 2010-2013.

4. Adanya kelengkapan data laporan keuangan antara 0 dan 1.Nilai $\mathrm{R}^{2}$ yang kecil berarti kemampuan variabel - variabel independen dalam menjelaskan variabel dependen sangat terbatas (Ghozali, 2005).Nilai yang mendekati satu/ 1 berarti variabel - variabel independen memberikan hamper semua informasi yang dibutuhkan untuk memprediksi variasi variabel dependen.

yang dipublikasikan sehingga

dapat digunakan dalam penelitian yaitu rasiorasio keuangan current ratio, debt to equity ratio, inventory turn over dan return on assets

Berdasarkan kriteria yang ditentukan terdapat 17 perusahaan automotive and allied products yang datanya sesuai dengan kebutuhan penelitian ini. Hasil statistik data variabel-variabel yang digunakan dalam penelitian ini dan telah dilakukan pengolahan data adalah sebagai berikut:

\section{Deskripsi Analisis Data}

Deskripsi analisis data yang akan berdasarkan minimum, maximum, mean dan standard deviasi adalah sebagai berikut:

\begin{tabular}{|l|l|l|l|l|l|}
\hline & $\mathrm{N}$ & MIN & MAX & MEAN & $\begin{array}{l}\text { STD. } \\
\text { DEV }\end{array}$ \\
\hline ROA & 85 & 11 & 26,90 & 4,2546 & 26,90 \\
\hline ITO & 85 & 19 & 13,76 & 4,8005 & 3,06170 \\
\hline DER & 85 & 23 & 14,38 & 1,5818 & 2,07666 \\
\hline CR & 85 & 48 & 4,02 & 1,6545 & 6,9734 \\
\hline
\end{tabular}

1. Return on asset (Y)

Dari tabel stastistik di atas dapat diketahui bahwa nilai minimum ROA sebesar 11 dan nilai maksimum 26,90. Hasil tersebut menunjukkan besarnya ROA perusahaan Automotive and Allied products yang menjadi sampel penelitian ini berkisar antara 11sampai 26,90 dengan rata-rata 4,2546 pada standar deviasi 26,90. Nilai rata - rata (mean) lebih besar dari standar deviasi yaitu 4,2546>26,90 berarti bahwa sebaran nilai ROA baik.

2.Current ratio $(\mathrm{X} 1)$

Dari tabel stastistik di atas dapat diketahui bahwa nilai minimum CR sebesar 48 dan nilai maksimum 4,02. Hasil tersebut menunjukkan besarnya ITO perusahaan Automotive and Allied products yang menjadi sampel penelitian ini berkisar antara 48 sampai 4,02 dengan rata-rata 1,6545 pada standar deviasi 6,9734. Nilai rata - rata (mean) lebih besar dari standar deviasi yaitu 6,9734> 1,6545 berarti bahwa sebaran nilai baik.

2.Inventory turn over (X2)

Dari tabel stastistik di atas dapat diketahui bahwa nilai minimum ITO sebesar 19 dan nilai maksimum 13,76. Hasil tersebut menunjukkan besarnya ITO perusahaan Automotive and Allied products yang menjadi sampel penelitian ini berkisar antara 19 sampai 13,76 dengan rata-rata 4,8005 pada standar deviasi 3,06170. Nilai rata - rata (mean) lebih besar dari standar deviasi yaitu 4,8005 > 3,06170 berarti bahwa sebaran nilai baik.

3,Debt Equity To Ratio (X3)

Dari tabel stastistik di atas dapat diketahui bahwa nilai minimum ITO sebesar 23 dan nilai maksimum 4,02. Hasil tersebut menunjukkan besarnya DER perusahaan 
Automotive and Allied products yang menjadi sampel penelitian ini berkisar antara 48 sampai 4,02 dengan rata-rata 1,5818 pada standar deviasi 2,076666. Nilai rata - rata (mean) lebih besar dari standar deviasi yaitu 1,5818> 2,07666 berarti bahwa sebaran nilai baik.

\section{Pengujian Asumsi Klasik}

Uji asumsi klasik digunakan untuk mengetahui keadaan data yang digunakan penelitian. Karena data yang digunakan adalah data sekunder, maka untuk menentukan ketepatan model perlu dilakukan pengujian atas beberapa asumsi klasik yaitu: uji normalitas, multikolinieritas, heteroskedasitas dan autokorelasi yang secara rinci dapat dijelaskan sebagai berikut:

\section{Normalitas}

Uji normalitas bertujuan menguji apakah dalam model regresi, variabel dependen dan variabel independen keduanya mempunyai

\section{Tabel}

distribusi normal atau tidak. Model regresi yang baik adalah memiliki distribusi normal atau mendekati normal. Untuk mendeteksi normalitas dapat dilakukan dengan uji statistic. Tes statistic yang digunakan antara lain analisis grafik histogram, normal probability plots dan kolmogorov - smirnov test (Imam Ghozali, 2001).

Kriteria uji kolmogorov - smirnov adalah sebagai berikut :

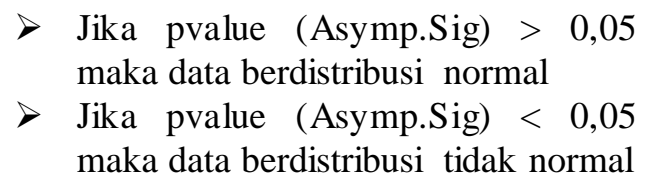

Hasil pengujian normalitas data dengan uji kolmogorov - Smirnov dapat dilihat pada tabel berikut ini.

\begin{tabular}{|c|c|c|c|c|c|}
\hline \multicolumn{6}{|c|}{ One-Sample Kolmogorov-Smirnov Test } \\
\hline & & $\begin{array}{c}\text { current } \\
\text { ratio (CR) }\end{array}$ & $\begin{array}{c}\text { debt to } \\
\text { equity ratio }\end{array}$ & $\begin{array}{l}\text { inventory } \\
\text { turnover }\end{array}$ & $\begin{array}{c}\text { profitabilitas } \\
(\mathrm{ROA})\end{array}$ \\
\hline \multicolumn{2}{|l|}{$\bar{N}$} & 85 & 85 & 85 & 85 \\
\hline \multirow[t]{2}{*}{ Normal Parameters ${ }^{a, b}$} & Mean & 1,8365 & 1,9340 & 5,7731 & 4,7011 \\
\hline & Std. Deviation &, 79135 & 2,24042 & 3,57762 & 4,40552 \\
\hline \multirow{3}{*}{$\begin{array}{l}\text { Most Extreme } \\
\text { Differences }\end{array}$} & Absolute & , 100 & ,268 & 086 & ,257 \\
\hline & Positive &, 100 & 268 & 086 & 257 \\
\hline & Negative &,- 080 &,- 223 &,- 084 &,- 189 \\
\hline Kolmogorov-Smirnov Z & & ,921 & 2,469 &, 790 & 2,368 \\
\hline Asymp. Sig. (2-tailed) & & ,365 & 190 &, 560 &, 545 \\
\hline
\end{tabular}

\section{Sumber ; Output SPSS versi 17; One Sample Kolmogrov Smirnov}

Hasil sampel pada tabel 4.1 tersebut $0,560>$ dari 0,05). Jadi tidak dapat menolak menunjukkan bahwa nilai kolmogrov - smirnov $\quad$ H0 yang mengatakan bahwa residual untuk:

1. Current ratio sebesar 0,921 dan tingkat signifikan pada 0,365 (karena $\mathrm{p}=0,365>$ dari 0,05$)$. Jadi tidak dapat menolak H0 yang mengatakan bahwa residual terdistribusi secara normal atau dengan kata lain residual berdistribusi normal.

2. Debt to equity ratio sebesar 2,469 dan tingkat signifikan pada 0,190 (karena $\mathrm{p}=$ $0,190>$ dari 0,05). Jadi tidak dapat menolak H0 yang mengatakan bahwa residual terdistribusi secara normal atau dengan kata lain residual berdistribusi normal.

3. Inventory Turn Over sebesar 0,790 dan tingkat signifikan pada 0,560 (karena $\mathrm{p}=$ terdistribusi secara normal atau dengan kata lain residual berdistribusi normal.

4. Return On Assets sebesar 2,368 dan tingkat signifikan pada 0,545 (karena $\mathrm{p}=0,545$ > dari 0,05). Jadi tidak dapat menolak H0 yang mengatakan bahwa residual terdistribusi secara normal atau dengan kata lain residual berdistribusi normal.

Pengujian normalitas data adalah pengujian tentang kenormalan distribusi data. Uji normalitas bertujuan menguji apakah dalam model regresi memiliki distribusi normal. Uji normalitas diuji dengan menggunakan uji Kolmogorov Smirnov dengan membuat hipotesis. 
Hipotes yang digunakan adalah:

H0 : Data residual berdistribusi normal

$\mathrm{Ha}$ : Data residual tidak berdistribusi normal

Data ini lolos uji masalah apabila nilai Asymp.Sig (2-tailed) variabel residual berada diatas 0,05. Sebaliknya jika nilai Asymp.Sig (2tailed) variabel residual berada dibawah 0,05, maka data tersebut mengalami normalitas (Ghozali, 2011: 160).

Uji Multikolinieritas

Uji Multikolinieritas bertujuan untuk menguji apakah dalam model regresi ditemukan adanya korelasi antara variabel indepen (Ghozali, 2011: 105). Jika ada korelasi yang tinggi antara variabel independen tersebut, maka hubungan antara variabel dependen dan independen menjadi terganggu. Model regresi Tabel Hasil Uji Mul tikolinieritas

\begin{tabular}{|l|l|l|l|}
\hline \multirow{2}{*}{ Var } & Collinearity statistic & \multirow{2}{*}{ Keterangan } \\
\cline { 2 - 3 } & Tolerence & VIF & \\
\hline CR & 0,870 & 1,149 & Bebas multikolonieritas \\
\hline ITO & 0,789 & 1,268 & Bebas multikolonieritas \\
\hline DER & 0,842 & 1,187 & Bebas multikolonieritas \\
\hline
\end{tabular}

Sumber: Output SPSS data diolah 2015

Hasil dari uji VIF pada table 4.1.1.2 menunjukkan bahwa ketiga variabel independen tidak terjadi multikolonieritas karena nilai VIF $<10$ dan TOL $>0,1$. Hal ini dapat dilihat besarnya nilai tolerance untuk variabel CR,ITO dan DER. Nilai tolerance semua variabel diatas 0,1 . Sedangkan nilai VIF dari variabel CR,ITO dan DER, nilai VIF semua variabel dibawah 10. Dengan demikian keempat variabel independen (CR,ITO dan DER) dapat digunakan untuk memprediksi ROA selama periode pengamatan.

\section{Uji Heteroskedastisitas}

Model regresi yang baik adalah yang homoskedastisitas atau tidak terjadi heteroskedasitas. Deteksi ada tidaknya problem heteroskedasitas adalah dengan media scatterpolt, apabila grafik membentuk pola khusus maka model terjadi heteroskedasitas. Tetapi jika ada pola yang jelas, serta titik titik menyebar si atas dan di bawah angka 0 pada sumbu Y, maka tidak terjadi heteroskedasitas.

Hasil uji heteroskedastisitas sebagai berikut : yang baik seharusnya tidak terjadi multikolinieritas. Multikolinieritas dapat dilihat dari nilai tolerance dan VIF (Variance Inflation multikolinieritas, nilai tolerance harus $\leq 0,1$ dan nilai VIF $\geq 10$ (Ghozali, 2011: 105-106). Ringkasan hasil uji multikolineritas disajikan pada tabel berikut:

Untuk mendeteksi ada tidaknya gejala variabel independen yang digunakan (CR, DER, ITO) dapat dilihat pada table 4.2 sebagai berikut: Factor). Untuk bebas dari masalah 


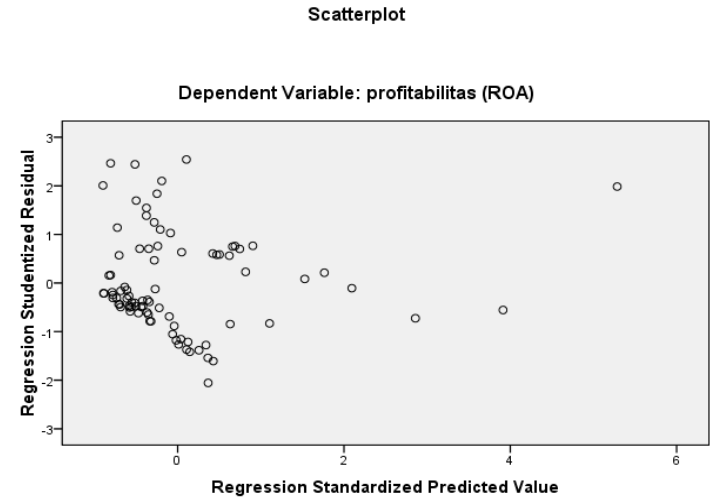

Sumber: output SPSS, data diolah, 2015

Grafik scatter plots pada kedua model regresi memperlihatkan bahwa titik - titik pada grafik tidak membentuk bisa membentuk pola tertentu yang jelas, dimana titik - titik menyebar di atas dan di bawah angka 0 pada sumbu Y, sehingga grafik tersebut tidak bias dibaca dengan jelas. Hasil ini memperlihatkan bahwa tidak terjadi heteroskedasitas.

\section{Uji Autokorelasi}

Autokorelasi sering dikenal dengan nama korelasi serial dan sering ditemukan pada data serial waktu (time series). Uji autokorelasi bertujuan menguji apakah dalam model regresi ada korelasi antara kesalahan penggunaan pada periode $\mathrm{t}$ dengan kesalahan penggunaan pada periode $\mathrm{t}-1$ (sebelumnya). Model regresi yang baik adalah regresi yang bebas dari autokorelasi. Alat ukur yang digunakan untuk mendeteksi adanya autokorelasi dalam penelitian ini menggunakan Tes Durbin Watson (D-W). Uji Durbin Waston hanya digunakan untuk autokorelasi tingkat satu (first order autocorrelation) dan mensyaratkan adanya intercept (konstanta) dalam model regresi dan tidak ada variabel lag di antara variabel independen. Hasil uji autokorelasi ini dapat dilihat pada tabel 4.3 .4 berikut ini:

Tabel

Uji Autokorelasi

Model Summary

\begin{tabular}{|l|r|r|r|r|}
\hline Model & $\mathrm{R}$ & $\mathrm{R}$ Square & $\begin{array}{c}\text { Adjusted } \\
\mathrm{R} \text { Square }\end{array}$ & $\begin{array}{r}\text { Std. Error of } \\
\text { the Estimate }\end{array}$ \\
\hline 1 &, $759^{\mathrm{a}}$ &, 576 &, 560 & 2,92247 \\
\hline
\end{tabular}

a. Predictors: (Cons tant), inventory turnover, current ratio (CR), debt to equity ratio

\section{\begin{tabular}{|c|}
\hline $\begin{array}{c}\text { Durbin- } \\
\text { Watson }\end{array}$ \\
\hline 1,564 \\
\hline
\end{tabular}}

R), debt to

b.dependent variable : return on assets

Berdasarkan tabel 4.2.4 uji autokorelasi dapat diketahui bahwa nilai DW sebesar 1,564Penyimpangan autokorelasi dalam penelitian diuji dengan uji Durbin-Watson (DW- test). Hal tersebut untuk menguji apakah model linier mempunyai korelasi antara disturbence error pada periode $\mathrm{t}$ dengan kesalahan pada periode $\mathrm{t}-1$ (sebelumnya). Hasil regresi dengan level of significance $0.05 \quad(\alpha=0.05)$ dengan 
sejumlah variabel independen $(\mathrm{k}=3)$ dan banyaknya data $(\mathrm{n}=17)$. Berdasarkan hasil hitung Durbin Watson, penyimpangan autokorelasi sebesar 1,564; sedangkan dalam tabel DW untuk " $\mathrm{k}$ " $=3$ dan $\mathrm{N}=17$ besarnya DWtabel: $\mathrm{dl}($ batas luar $)=1,116$; du (batas dalam $)=$ 1,$879 ; 4-\mathrm{du}=2,121$; dan $4-\mathrm{dl}=2,584$ maka dari perhitungan disimpulkan bahwa DW-test terletak pada daerah uji.Hal tersebut menunjukkan bahwa Durbin Watson berada di daerah no autocorrelation, artinya pada data rasio-rasio keuangan yang digunakan dalam penelitian ini tidak terdapatkesalahan data yang dipengaruhi oleh kesalahan pada periode tahun sebelumnya.

\section{Hasil Pengujian Hipotesis}

Untuk menguji hipotesis yang ada pada penelitian ini perlu dilakukan analisis statistik terhadap data yang telah diperoleh. Analisis statistik yang digunakan dalam penelitian ini adalah regresi. (Ghozali, 2011) menyatakan bahwa dalam uji regresi khususnya uji t dan uji F sangat dipengaruhi oleh nilai residual yang mengikuti distribusi normal, sehingga jika asumsi ini menyimpang dari distribusi normal maka menyebabkan uji stastistik menjadi tidak valid. Oleh karena itu, jika terdapat data yang menyimpang dari sebarannya, maka data tersebut tidak disertakan dalam analisis.

Hipotesis pertama, kedua, ketiga dan keempat pada penelitian akan diuji parsial (Ujit) untuk mengetahui apakah variabel bebas individu berpengaruh terhadap variabel terikat. Uji model akan diuji menggunakan uji simultan (Uji F) untuk mengetahui pengaruh variabel bebas terhadap variabel terikat secara simultan. Sebelum melakukan uji-t dan uji F maka dilakukan pengujian uji regresi linier berganda sebagai berikut:

\section{Uji Regresi Linier Berganda}

Regresi linier berganda ingin menguji pengaruh dua atau lebih variabel independen terhadap satu variabel dependen (Ghozali, 2009) yang dinyatakan sebagai berikut:

$\mathrm{Y}=\alpha+(\beta 1 \cdot \mathrm{CR})+(\beta 2 \cdot \mathrm{ITO})+(\beta 3 \cdot \mathrm{DER})+\mathrm{e}$

$\mathrm{Y}=-0,841+0,821 \mathrm{CR}+1,053 \mathrm{DER}+0,346 \mathrm{ITO}$

Untuk mengetahui pengaruh variabel dependen yaitu return saham terhadap variabel independen yaitu current ratio, inventory turn over, dan debt to equity ratio. Hasil yang diperoleh selanjutnya akan diuji kemaknaan model tersebut secara simultan dan secara parsial. Berdasarkan data diperoleh hasil regresi linier berganda sebagai berikut:

Tabel

Hasil Analisis Regresi

\begin{tabular}{|l|l|l|l|l|l|}
\hline Model & \multicolumn{2}{|l|}{$\begin{array}{l}\text { Unstandardized } \\
\text { coefficient }\end{array}$} & \multicolumn{2}{l|}{$\begin{array}{l}\text { Standardized } \\
\text { coefficient }\end{array}$} & \\
& B & $\begin{array}{l}\text { Std. } \\
\text { error }\end{array}$ & Beta & t & sig \\
\hline (constant) & -841 &, 883 & & -953 & 343 \\
\hline CR &, 821 &, 232 &, 247 & 2,900 & 0,031 \\
\hline ITO &, 346 &, 097 &, 281 & 3,563 & 0,001 \\
\hline DER & 1,053 &, 160 &, 536 & 6,574 & 0,000 \\
\hline
\end{tabular}

Sumber :output spss, data diolah 2015

Koefisien-koefisien persamaan regresi linier berganda pada tabel 4.3.1. dapat diartikan sebagai berikut:

1. Konstanta $(\alpha)$ sebesar $-0,841$ mempunyai arti apabila semua variabel independen sama dengan nol maka return on assets saham perusahaan automotive and allied products bernilai sebesar 0,841 .

2. Koefisien regresi $\mathrm{CR}$ sebesar 0,821 artinya setiap kenaikan rasio $\mathrm{CR}$ sebesar 1 satuan menaikkan return on assets saham sebesar 0,821 dengan asumsi faktor - faktor yang lain tetap atau ceteris paribus.

3. Koefisien regresi ITO 0,346 mempunyai arti setiap kenaikan rasio ROA sebesar 1 satuan akan menurunkan return on assets saham perusahaan automotive and allied products sebesar 0,346 satuan dengan asumsi faktor - faktor yang lain tetap atau ceteris paribus.

4. Koefisien regresi DER sebesar 1,053 artinya setiap kenaikan rasio DER sebesar 1 satuan menurunkan return on assets saham sebesar 
1,053 satuan dengan asumsi faktor - faktor yang lain tetap atau ceteris paribus.

\section{Uji Parsial (Uji-t)}

Uji statistik $t$ pada dasarnya menunjukkan seberapa jauh pengaruh satu variabel penjelas/independen secara individual dalam menerangkan variasi variabel dependen (Ghozali, 2011).

Koefisien regresi digunakan untuk mengetahui pengaruh variabel CR, ITO, dan DER secara parsial terhadap return on assets. Kriteria pengujian adalah:

1. Jika tingkat signifikansi lebih dari $5 \%$ maka dapat disimpulkan bahwa Ho diterima, sebaliknya Ha ditolak.

2. Jika tingkat signifikansi lebih kecil dari $5 \%$, maka dapat disimpulkan bahwa Ho ditolak, sebaliknya Ha diterima

Tabel

Hasil Uji - t

\begin{tabular}{|c|c|c|c|c|c|c|c|c|}
\hline No & var & \multicolumn{2}{|c|}{$\begin{array}{c}\text { Bobot } \\
\text { pengaruh }\end{array}$} & & \multicolumn{2}{c|}{$\begin{array}{c}\text { Signifikansi } \\
\boldsymbol{\alpha}=\mathbf{0 , 0 5}\end{array}$} & \multirow{2}{*}{ Keter } \\
\cline { 3 - 7 } & & $\begin{array}{c}\mathbf{T} \\
\text { hitun } \\
\mathbf{g}\end{array}$ & $>/<$ & T tabel & Pvalue & $>/<$ & sig & \\
\hline 1 & CR & 3,939 & $>$ & 1,6630 & 0,000 & $<$ & 0,05 & H1 diterima \\
\hline 2 & ITO & 5,541 & $>$ & 1,6630 & 0,000 & $<$ & 0,05 & H2 diterima \\
\hline 3 & DER & 8,753 & $>$ & 1,6630 & 0,000 & $<$ & 0,05 & H3 diterima \\
\hline 4 & ROA & 5,541 & $>$ & 1,6630 & 0,000 & $<$ & 0,05 & H4 diterima \\
\hline
\end{tabular}

Sumber : output SPSS, data diolah 2015

Variabel ROA memiliki koefisien arah positif sedangkan CR, ITO dan DER memiliki koefisien negatif. Hasil pengujian pengaruh variabel independen terhadap variabel dependennya sebagai berikut:

1. Pengujian hipotesis pertama

Ha1 : Current ratio (CR) berpengaruh positif terhadap return on assets.

Berdasarkan pada tabel 4.3.2 hasil uji regresi linier berganda diperoleh nilai koefisien regresi untuk sebesar 0,821. Hal ini menunjukkan bahwa hubungan antara CR terhadap return on assets adalah tidak searah. Variabel CR (X1) mempunyai $\mathrm{t}$ hitung sebesar 3,939 dengan signifikansi sebesar 0,000 . Nilai signifikansi t $\mathrm{CR}<0,05$ maka dapat disimpulkan CR berpengaruh terhadap return on assets sehingga hipotesis pertama diterima.

iperoleh nilai koefisien regresi untuk DER diperoleh nilai sebesar 1,053. Hal ini menunjukkan bahwa hubungan antara DER terhadap return saham tidak searah. Variabel DER (X3) mempunyai $t$ hitung sebesar 6,574dengan signifikansi sebesar 0,000. Nilai signifikansi $\mathrm{t}$ DER $<0,05$ maka dapat disimpulkan DER berpengaruh positif terhadap return on assets sehingga hipotesis ketiga diterima.

\section{Uji Signifikansi Simultan (Uji F)}

\section{Pengujian Hipotesis Kedua}

$\mathrm{Ha} 2$ : ITO berpengaruh positif terhadap return on assets

Berdasarkan pada tabel 4.3.2 hasil uji regresi linier berganda diperoleh nilai koefisien regresi untuk ROA sebesar 0,346. Hal ini menunjukkan bahwa hubungan antara CR terhadap return saham adalah searah. Variabel CR (X2) mempunyai $\mathrm{t}$ hitung sebesar 3,563 dengan signifikansi sebesar 0,001. Nilai signifikansi t ROA $<0,05$ maka dapat disimpulkan ROA berpengaruh positif dan signifikan terhadap return saham sehingga hipotesis kedua diterima.

3. Pengujian Hipotesis Ketiga

Ha3 : DER berpengaruh positif terhadap return on assets

Berdasarkan pada tabel 4.3.2 hasil uji regresi linier berganda

Uji $F$ digunakan untuk menguji signifikansi model regresi. Tujuan dari uji $\mathrm{F}$ ini adalah untuk membuktikan secara statistik bahwa keseluruhan koefisien regresi yang digunakan dalam analisis ini signifikan. Apabila nilai signifikansi $\mathrm{F}$ lebih kecil dari 0,05 maka model regresi signifikan secara statistik.

Untuk menguji hipotesis ini digunakan statistik $F$ dengan kriteria pengambilan keputusan sebagai berikut:

a) Bila nilai $F$ lebih besar daripada 4 maka Ho dapat ditolak pada derajat kepercayaan 5\%, 
dengan kata lain menerima Ha yang menyatakan bahwa semua variabel independen secara simultan signifikan mempengaruhi variabel dependen.

\section{Uji F}

\section{Tabel}

b) Membandingkan nilai $F$ hasil perhitungan dengan nilai $\mathrm{F}$ menurut tabel. Bila nilai $\mathrm{F}$ hitung lebih besar daripada nilai $\mathrm{F}$ tabel, maka Ho ditolak dan menerima Ha. (Ghozali, 2011).

\begin{tabular}{|c|c|c|c|c|c|c|}
\hline \multicolumn{7}{|c|}{ ANOVA } \\
\hline Model & & $\begin{array}{l}\text { Sum of } \\
\text { Squares }\end{array}$ & df & Mean Square & $\mathrm{F}$ & Sig. \\
\hline \multirow[t]{3}{*}{1} & Regression & 256,723 & 1 & 256,723 & 15,513 &, $000^{2}$ \\
\hline & Residual & 1373,600 & 83 & 16,549 & & \\
\hline & Total & 1630,324 & 84 & & & \\
\hline
\end{tabular}

a. Predictors : (Constant), current ratio (CR)

b. Dependent Variable: profitabilitas (ROA)

Pengujian signifikansi pengaruh variabel Current Ratio, Debt To Equity Ratio dan inventory turn over terhadap return on assets secara simultan dapat dilihat pada tabel 4.5 uji simultan, bahwa nilai $\mathrm{F}$ hitung sebesar 15,513 dengan signifikansi sebesar 0,00. Nilai signifikansi $0,000<0,05$ menunjukkan bahwa variabel CR, DER dan ITO secara simultan mempunyai pengaruh terhadap return saham sehingga hipotesis diterima.

\section{Pembahasan}

1. Pengaruh CR terhadap Return Saham

Koefisiensi regresi variabel CR yaitu sebesar 0,821 . Hal ini menunjukkan bahwa hubungan antara CR terhadap return saham adalah searah. Hasil uji koefisien regresi diperoleh nilai $\mathrm{t}$ hitung sebesar 3,939 dengan signifikansi 0,000 apabila dibandingkan dengan tingkat signifikansi yang diharapkan yaitu $5 \%$ berarti t hitung lebih besar dari tingkat signifikansi yang diharapkan $(0,000<0,05)$. Maka dapat disimpulkan bahwa CR berpengaruh terhadap return saham sehingga hipotesis pertama ditolak. Dalam penelitian ini CR menunjukkan hasil positif dan signifikan. CR berpengaruh terhadap return on assets, artinya perusahaan yang memiliki CR tinggi tentu akan menghasilkan return saham yang tinggi pula. Nilai $C R$ yang tinggi menunjukkan bahwa ketersediaan aktiva lancar guna melunasi kewajiban lancar juga tinggi. Sedangkan aktiva lancar berisi akun-akun seperti kas dan setara kas, piutang, persediaan dan surat berharga. Namun dengan tingginya $\mathrm{CR}$ belum tentu menjamin perusahaan mempunyai cukup kas untuk memenuhi kewajiban lancarnya.

Hasil ini konsisten dengan penelitian yang telah dilakukan oleh Tuasikal (2002) yang hasilnya menunjukkan bahwa current ratio memiliki pengaruh yang positif dan signifikan terhadap return on assets.

2. Pengaruh ITO terhadap Return on assets

Koefisiensi regresi variabel bertanda positif $(+)$ yaitu sebesar 0,346. Hal ini menunjukkan bahwa hubungan antara ITO terhadap return on assets adalah searah. Hasil uji koefisien regresi diperoleh nilai t hitung sebesar 3,563 dengan signifikansi 0,001 apabila dibandingkan dengan tingkat signifikansi yang diharapkan yaitu $5 \%$ berarti $\mathrm{t}$ hitung lebih kecil dari tingkat signifikansi yang diharapkan $(0,001<0,05)$. Maka dapat disimpulkan bahwa ITO berpengaruh positif dan signifikan terhadap return on assets sehingga hipotesis kedua diterima.

ITO yang tinggi dapat diartikan bahwa perusahaan nventory turnover menunjukkan kemampuan dana yang tertanam dalam inventory berputar dalam suatu periode tertentu, sebaliknya tingkat ITO yang rendah menunjukkan perusahaan yang tidak efesien dan tidak berhasil memberdayakan dananya. Semakin tinggi ITO menunjukkan efisiensi operasional, yang memperlihatkan seberapa baiknya manajemen mengontrol modal yang ada pada persediaan. Hasil ini konsisten dengan penelitian yang telah dilakukan olehAsyik dan sulistyo (2000) yang hasilnya menunjukkan 
bahwa ITO memiliki pengaruh yang positif dan signifikan terhadap return on assets.

3.Pengaruh DER terhadap Return On Assets

Koefisiensi regresi variabel DER bertanda negatif (+) yaitu sebesar 1,053. Hal ini menunjukkan bahwa hubungan antara DER terhadap return saham adalah searah. Hasil uji koefisien regresi diperoleh nilai t hitung sebesar 6,574 dengan signifikansi 0,000; apabila dibandingkan dengan tingkat signifikansi yang diharapkan yaitu 5\% berarti t hitung lebih besar sar pada beban perusahaan terhadap pihak luar karena akan meningkatkan solvabilitas perusahaan. Hal ini dikarenakan perusahaan akan berusaha memenuhi kewajiban hutangnya dahulu sebelum memberikan return pada investor. Semakin tinggi DER mencerminkan risiko perusahaan yang relatif tinggi, akibatnya para investor cenderung menghindari sahamsaham yang memiliki nilai DER yang tinggi. Hasil ini konsisten dengan penelitian yang telah dilakukan oleh Metha (2012) menunjukkan

Tabel

Koefisien determinasi (Adjusted $\mathbf{R}^{2}$ ) Model summary

Model Summary

\begin{tabular}{|l|r|r|r|r|}
\hline Model & $\mathrm{R}$ & $\mathrm{R}$ Square & $\begin{array}{c}\text { Adjusted } \\
\text { R Square }\end{array}$ & $\begin{array}{c}\text { Std. Error of } \\
\text { the Estimate }\end{array}$ \\
\hline 1 &, $759^{\mathrm{a}}$ &, 576 &, 560 & 2,92247 \\
\hline
\end{tabular}

a. Predictors: (Cons tant), inventory turnover, current ratio $(\mathrm{CR})$, debt to equity ratio

Berdasarkan table 4.5 dapat dilihat angka koefisien determinasi ( Adjusted R square) sebesar 0,560 atau 56\%. Hal ini menunjukkan bahwa variabel independen berupa current ratio, inventory turn over dan debt to equity ratio dapat menjelaskan variabel dependen (return on assets) sebesar 56\% sisanya sebesar $44 \%$ dijelaskan oleh variabel - variabel lain di luar penelitian ini.

\section{SIMPULAN, KETERBATASAN DAN IMPLIKASI}

Dari hasil analisis data maka diambil kesimpulan:

1. CR (X1) secara parsial berpengaruh positif terhadap return on assets pada perusahaan automotive and allied products di Busa Efek Indonesia periode 2010-2013. Hasil tersebut dibuktikan dengan hasil signifikansi t sebesar 0,000 . dari tingkat signifikansi yang diharapkan $(0,000$ $<0,05)$. Maka dapat disimpulkan bahwa DER berpengaruh terhadap return on assets.

Debt to equity ratio menggambarkan struktur modal perusahaan yang digunakan sebagai sumber pendanaan usaha. DER negatif berarti semakin tinggi debt to equity ratio menunjukkan semakin tinggi komposisi utang perusahaan dibandingkan dengan modal sendiri sehingga berdampak

be

adanya pengaruh positif DER terhadap kinerja perusahaan.

\section{Koefisien Determinasi (adjusted $\mathbf{R}$ square)}

Pada bagian ini dilakukan uji koefisien determinasi untuk menggambarkan seberapa besar perubahan atas variasi dari variable dependen yang dapat dijelaskan oleh perubahan atau variasi dari variabel independen. Koefisien determinasi atau adjusted $\mathrm{R}^{2}$ dapat dilihat pada tabel berikut: 
0,000 yang lebih kecil dari 0,05. Nilai Adjusted $\mathrm{R}$ Square sebesar 0,261 menunjukkan bahwa perubahan yang terjadi pada return on assets dapat dijelaskan oleh CR, ITO dan DER sebesar $26.1 \%$ dan sisanya $73,9 \%$ dijelaskan oleh variabel lain.

\section{Keterbatasan penelitian Dan Saran}

Penelitian ini masih mempunyai beberapa keterbatasan diantaranya:

1. Keterbatasan dalam mengambil jenis perusahaan yang digunakan sebagai sampel dalam penelitian ini hanya perusahaan automotive and allied products saja, sehingga tidak mencerminkan pasar modal secara keseluruhan.

2. Keterbatasan dalam menggunakan rasio keuangan perusahaan hanya diwakili oleh tiga buah rasio keuangan, yaitu Current Ratio, Inventory Turn Over dan Debt to Equity Ratio. Sebab terdapat kemungkinan rasio-rasio keuangan lain yang lebih signifikan pengaruhnya terhadap perubahan return on Assets. Bagi penelitian berikutnya diharapkan menambah rasio keuangan lainnya sebagai variabel independen, karena sangat mungkin rasio keuangan lain yang tidak dimasukkan dalam penelitian ini berpengaruh terhadap perubahan harga saham kaitannya dengan return on assets.

\section{Daftar pustaka}

Algifhari, "Analisis regresi,teori, kasus dan solusi", BPFE Yogyakarta, 2003

Asyik,nur fajrih dan sulistyo 2000. “ kemampuan rasio keuangan dalam memprediksi laba (penetapan rasio keuangan sebagai discriminator)" jurnal ekonomi dan bisnis Indonesia, vo. 15 no. 3: 313 - 331

Brigham, Eugene F. dan Joe F Houston. 2001.

Manajemen Keuangan, Jakarta : Erlangga

Brigham, F. Eugene. 1983. Fudamental of Financial Management, The Dryden Press: Holt-Soundersn Japan, Third Edition.

Barbosa, Natalia and Helen louri (2003). "corporate performance, does ownership matter? A comparison of foreign and domestic owned firms in Greece and portugal" working papper series no. 26.
Campbell, Kevin (2002) “ ownership structure and the operating performance of Hungarian firms," working papper no. 9.

Gujarati, Damodar, 1995. "Basic Econometrics" alih bahasa sumarno zain, ekonometrika dasar, penerbit erlangga, Jakarta

JohN. T.A. "Accounting measures of corporate liquidity, leverage and costs of financial distress." Financial management, autumn, 32,3 pp 91-110, 1993

Imam Ghozali, 2005. Aplikasi analisis Multivariate dengan program SPSS, Semarang: BP UNDIP.

Indonesian capital market directory 2010 Indonesian capital market directory 2011 Indonesian capital market directory 2012 Indonesian capital market directory 2013 Iskandar Rusli, 2009. " Pengaruh Asset Dan Manajemen Inventory Terhadap Manajemen Laba". Bisnis dan birokrasi, jurnal ilmu administrasi dan organisasi, sep - des. 160 169.

Ni Made Vironika Sari1 I G.A.N. Budiasih (2014), "Pengaruh debt to equity ratio, Firm size, Inventory Turnover Dan Assets Turnover Pada Profitabilitas". E-Jurnal Akuntansi Universitas Udayana 6.2 (2014):261-27)

Padachi, Kesseven. 2006. Trends in Working Capital Management and Its Impact on Firm's Performance : An Analysis of Mauritian Small Manufacturing Firms. http://www.docstoc.com/docs/DownloadDoc.asp $\underline{x}$ ?doc id=20721861\&ref url

Rahmawati, linda fitri (2009), "Pengaruh Current Ratio, Inventory Turnover, Dan Debt To Equity Ratio Terhadap Return On Assets (Studi pada Perusahaan Food and Beverage yang Listing di Bursa EfekIndonesia tahun 20072009), karya ilmiah universitas negeri Malang

Robert Ang, 1997. “ Buku P intar: Pasar Modal Indonesia (The Intelligent guide to IndonesianCapital Market )" Media Soft Indonesia, First Edition.

Sartono, Agus. 2001. Manajemen Keuangan Internasional. Edisi Pertama. Yogyakarta: BPFE. 
Santoso, Singgih. " statistic and products service solution/SPSS." Elex media computindo Jakarta 2000

Takon Samuel mayo and uguwe ike (2013), "The Effect Of Accounts Receivable On Return On Assets Of Selected Nigerian Firms", www.kompas.com
International Journal of current research vol. 5, issue, 12, pp. 3767 -3772, December 2013

www.idx.co.id 